\title{
Immigrant Assimilation and Charitable Giving
}

\author{
Una Okonkwo Osili ${ }^{1}$
}

Dan $\mathrm{Du}^{2}$

${ }^{1}$ Contact Information: Department of Economics, Indiana University - Purdue University Indianapolis, Indianapolis, IN 46202; phone: (317) 997-6536, email: uosili@iupui.edu.

2 Contact Information: Rand Graduate School, 1700 Main Street Santa Monica, CA 90407; phone: (310)393-0411, email: Dan_Du@rgs.edu. We gratefully acknowledge funding from the Center on Philanthropy at Indiana University. We have benefited greatly from comments from Mark Wilhelm, Rich Steinberg, and participants at the 2003 ARNOVA conference. Xiaojun Feng and Jeanne Ruan provided excellent research assistance 


\begin{abstract}
Will immigration impact economic progress and social cohesion in host countries? One indicator that can shed new light on the complex process of immigrant assimilation is charitable giving. Charitable giving and other forms of civic engagement may affect norms of trust, connectedness, and cooperative behavior. We find that immigrant status has a negative, but insignificant impact on the incidence and levels of charitable giving. There is considerable evidence that immigrants adapt rapidly to U.S. charitable institutions over time. Results on private transfers present a striking contrast. Immigrant households are significantly more likely to participate in private transfer networks.
\end{abstract}


It is often argued that successful integration of new immigrants into host societies is important for economic progress and social cohesion. Some researchers have cautioned that recent U.S. immigrants may not adapt rapidly due to significant differences in ethnicity, education, and skills from native-born population, which may lead to greater social and economic fragmentation. Yet, others have argued that immigrants are being incorporated into the mainstream, and may also have the potential to change mainstream society and culture.

To date, existing research within economics mainly focuses on language proficiency, wages, and occupational attainment as key indicators of immigrant assimilation. However, standard economic indicators provide very limited evidence on how immigration will impact social cohesion and institutions. ${ }^{3}$ To better understand how immigrants and their children will fit into American society now and in the future, it may be necessary to examine other aspects of the immigrant experience. In a growing body of work, scholars have examined socioeconomic attachments, crime, residential settlement, and patterns of intermarriage among immigrants. Butcher and Piehl (1998) find that immigrant youth are less likely to be engaged in crime than native youth and that immigrants appear to have no effect on crime rates after controlling for the demographic characteristics of cities. Lichter and Qian (2001) argue that recent waves of U.S. immigrants have lower rates of intermarriage and may face significant barriers to assimilation than earlier waves of immigrants.

One indicator that can shed new light on the complex process of immigrant assimilation is charitable giving. Charitable giving and other forms of civic engagement have been shown to affect norms of trust, connectedness, and the ability of individuals and communities to enhance their economic and social well-being through cooperative behavior (Putnam, 1993; 2000). Far more than reflecting cultural values and norms, by studying immigrant assimilation in charitable giving it is possible to learn how immigrants interact with American institutions and contribute to civic, social, and economic life.

In this paper, we examine immigrant assimilation in charitable giving. The results in this paper

\footnotetext{
${ }^{3}$ We define social cohesion as the level of interconnectedness within society, including the willingness to co-operate, trust and confidence in institutions, norms of reciprocity, and belonging. See (Dayton-Johnson, 2001) for a review of this literature. In recent years, building social cohesion and civil society have emerged as an important policy goal in the U.S., Canada, and the European Union, particularly in light of recent links between immigration policy and international terrorism events in the United States and Spain.
} 
are related to broad questions concerning the economic and social dimensions of immigrant assimilation. Our findings can also inform debates on the role that social identity and cultural origins play in shaping patterns of charitable giving and private transfer behavior.

The empirical analysis in this paper is based on new data from the Center on Philanthropy Panel Study (COPPS), a module in the Panel Study of Income Dynamics (PSID). These data represent the largest one-time study of philanthropy in the United States and provide a unique opportunity to study the role of immigrant status on both charitable giving and private transfers. We find that immigrant status has a negative, but insignificant impact on charitable giving, and there is considerable evidence that immigrants adapt rapidly to U.S. charitable institutions over time. Our results on private transfers present a striking contrast. Immigrant households are about 10 percentage points more likely to participate in private transfer networks. However, private transfer networks tend to be relatively persistent as immigrants gain U.S. experience. Our results on charitable giving, and to a lesser extent private transfer networks, provide some evidence that immigrants assimilate to American processes and institutions, and perhaps may also have the potential to shape social and civic life in the future.

The rest of the paper is organized as follows. Section II provides some background to this study. Section III presents an overview of the econometric methods used in this paper. Section IV describes the data. In Section V, we discuss results. Section VI presents conclusions.

\section{BACKGROUND}

In this study, we define charitable giving as contributions to qualified nonprofit organizations that are eligible for the charitable deduction according to the definitions provided by the Internal Revenue Service. Since a high proportion of charitable activity in the United States involves religious and educational institutions to which donors have close personal ties, it is likely that immigrant status will affect giving. Simon (1993) emphasizes the role of ethnic and religious ties, class and organizational loyalties, and nationalism as generators of altruistic actions. For example, volunteer experience in childhood and early adulthood and present-day religious commitment are related to donations of money and time. Individual charities are also more likely to attract donors if they use social networks such as a close friend, a clergyman, or a fellow worker to solicit a donation (Rose-Ackerman 1996). Schervish and Havens (1997) discuss the importance of "communities of participation" which refer to groups that potential donors are already involved with as a key indicator of charitable behavior. 
Despite the lack of quantitative sources on patterns of giving among U.S. immigrants, there is a growing body of descriptive literature that examines how ethnicity and cultural traditions affect giving patterns. Recent immigrants often arrive in the United States with their own traditions of giving based on experiences in the country of origin, which may differ from giving traditions of the native-born population (Joseph, 1995). ${ }^{4}$ Furthermore, recent immigrants may have lower levels of involvement with U.S. charitable institutions due to residential segregation and social networks.

We also examine private transfer behavior among immigrants and natives. Private transfers generally refer to transfers of money and goods to individuals living outside the household. There is some evidence that private transfers are common among immigrant households (O'Neill and Roberts, 2000). While there is likely to be a great deal of heterogeneity within immigrant populations, the contribution of time, goods, and money in less formal and more personal ways has been an important part of the U.S. immigration experience. Private transfers within extended family and social networks often include financial support towards education expenses, medical costs, and housing, and improve the ability of non-household recipients to cope with adverse shocks to income including those associated with unemployment and ill health (Chao, 1999). Migrants' family ties and social networks outside the United States may also affect patterns of private transfer behavior. Immigrants with immediate family members residing outside the United States may send remittances to family members or channel their resource transfers towards hometown organizations and community development projects. ${ }^{5}$

There is an extensive literature that documents the importance of private transfer networks in developing countries, where a growing share of U.S. immigrants originates (see Morduch, 1999 for a detailed review of this literature). Private transfers may be motivated by the altruistic ties and reciprocity norms that link family members and close friends as well as by exchange considerations. To understand transfer patterns among immigrants, Chao (1999) argues that immigrants may not often

\footnotetext{
${ }^{4}$ An important source within this literature is, Donors of Color (Council of Foundations, 1993), which uses qualitative methods to study traditions of giving within specific ethnic and cultural groups.

5 In 2001, remittances to developing countries amounted to $\$ 72.3$ billion, exceeding total official flows, and nearly 42 percent of total Foreign Direct Investment to developing countries (World Bank, 2003). In addition to financial transfers, immigrants may send clothing, food, and consumer goods to their family members in their origin communities.. This figure represents a lower bound for the scale of remittances since remittance flows may also occur through informal channels.
} 
recognize informal giving as philanthropy, but rather may consider this to be part of an individual's social obligation to family and social networks.

Our focus on immigrant assimilation in charitable giving fits into a broader literature on the economic and social adaptation of U.S. immigrants. Although the assimilation of immigrants in philanthropic activity is a relatively unexplored topic, there may be some parallels with the wage assimilation literature. ${ }^{6}$ In particular, levels and composition of formal and informal giving among U.S. immigrants may converge to that of the native-born population. It is likely that the rate of assimilation in charitable giving will depend on the immigrant's country of origin experience. Specifically the degree of similarity between philanthropic institutions in the country of origin and the host country may affect the rate of assimilation in charitable giving. Immigrants from ethnic traditions and countries with less-similar philanthropic institutions (compared to the U.S.) may assimilate at a slower rate compared with immigrants from countries with more similar philanthropic institutions, other things being equal.

There is also some evidence that assimilation among new immigrants, which is mainly composed of Latin American and Asian immigrants, may occur at a slower rate when compared to the pace of assimilation achieved by earlier waves of European immigrants (Borjas, 1994). ${ }^{7}$ There is likely to be a great deal of heterogeneity based on ethnicity and country of origin (Duleep and Regents, 1997) as some national origin groups appear to experience faster economic assimilation than others.

\section{EMPIRICAL SPECIFICATION}

In our empirical analysis, we examine the role of immigrant status on charitable donations $(G)$ and private transfers $(S)$. Our goal is to investigate the role of immigrant status and duration of stay in the United States on participation in charitable giving and private transfer networks. The rich set of socio-demographic variables available in the PSID also allows us to control for the role of religion, education, gender, ethnicity, and family networks, as well as the price of giving and income.

\footnotetext{
${ }^{6}$ Some studies of immigrant earnings, for example, Chiswick (1978), present a favorable picture of immigrant adaptation to the U.S. labor market. First, the earnings of immigrants grow rapidly as they gain experience in the United States; and second, this rapid growth leads to immigrants' earnings outpacing the earnings of the natives within 10-15 years.

${ }^{7}$ Borjas (1985) argues that the use of cross-sectional data may overstate the rate of wage assimilation. Using longitudinal data, Lubotsky (2000) finds that estimates of immigrant wage growth are lower than those provided by cross-sectional data from the decennial census. However, Duleep and Dowhan (2002) find that earnings growth among immigrants exceeds native wage growth even when longitudinal data is used.
} 
To study giving to charitable organizations and private transfers, we estimate the following empirical model:

$$
\begin{gathered}
\text { Give }=\beta_{0}+\beta_{I} \text { Immigrant }_{i}+\beta_{2}\left(\text { Duration }^{*} \text { Immigrant }\right)+\beta_{3} \text { Price of }_{\text {Giving }}+ \\
\beta_{4} \text { HouseholdCharacteristics }_{i}+\beta_{5} \text { Income }_{i}+u_{i} \\
u \mid \mathbf{x} \sim \operatorname{Normal}\left(0, \sigma^{2}\right) .
\end{gathered}
$$

Equation (1) represents the fully specified model. We build up to this model and first estimate a parsimonious specification, which includes an indicator variable for immigrant status. Our basic specification is a probit model, which captures the likelihood that a household has contributed to a charitable institution in the survey period. The parameter on the duration of stay variable measures how time in the United States affects the immigrant's likelihood of giving to a charitable institution. We estimate an identical specification for private transfers.

To study the impact of immigrant status and duration of stay on the amount contributed to charitable institutions and private transfer networks, we estimate a Tobit model. We observe charitable giving only if the total amount transferred is greater than $\$ 25$ for charitable donations. Similarly, we observe private transfers only where a household has made a positive net transfer to non-household members (excluding transfers to children and alimony payments). We measure the levels of charitable and informal giving as their natural logarithms. ${ }^{8}$ In addition, the price of giving, income, and wealth variables are also measured in logs such that their coefficients represent elasticities.

In our estimation, we recognize that giving to charitable institutions and private transfer networks may be interdependent. To account for the correlation of error terms, we also estimate a Bivariate probit and Tobit model.

\section{DATA}

The new PSID philanthropy module used in this paper is unique because it provides high-quality data on charitable giving, comparable to the U.S. Individual Taxpayer Return data ${ }^{9}$ (Wilhelm, 2002).

\footnotetext{
${ }^{8}$ More formally, our continuous measure of formal and informal giving is defined as $\log (1+$ total amount).

9 The PSID philanthropy module is the only data set on giving that is comparable to the IRS taxpayer data in coverage. However, we should note that the IRS taxpayer database provides a more accurate picture of charitable giving at and above the $90^{\text {th }}$ percentile of charitable giving. The IRS tax data is less suitable for this study because immigrant status and experience is not recorded, and immigrants may be less likely to itemize their deductions.
} 
Most existing data sources on U.S. charitable giving do not provide detailed information on charitable giving and high quality information on income and wealth.

In addition, the PSID contains detailed information on immigration experience through the immigration module. The PSID immigration module provides a comprehensive picture of immigration experience and settlement and includes a refresher sample of new immigrants (arrived in the United States after 1968). This 1997 migration module also provides information on immigrant status, country of origin, year of migration to the United States, and legal status upon arrival, as well as family networks in the U.S. and outside the U.S. ${ }^{10}$ The refresher sample of immigrants (about 441 immigrant families) was added to the PSID in 1997 in order to keep the study representative of the U.S. population.

Our data set contains 491 immigrant households and 4970 native households. ${ }^{11}$ Immigrant households refer to a household where either the head or spouse was born outside the United States. About 30 percent of the immigrant sample report U.S. citizenship. A large share of the immigrant sample was born in Mexico, Central and South America (about 58 percent of the immigrant sample). The average length of U.S. experience is 18.45 years. Nearly 18 percent of our immigrant sample can be classified as recent immigrants who arrived in the past ten years. About 80 percent of the immigrant sample has a parent or sibling residing outside the U.S.

The key dependent variables in our study are charitable giving and private transfers to non-household members (family, friends, relatives, and others). We examine "giving" as a dichotomous variable, which is equal to 1 if individual $i$ gave a transfer to a charitable organization or a private transfer in the survey year, and zero otherwise. We also investigate the amount transferred, a continuous variable, which is defined as the log of the total monetary contribution to a charitable organization, or log of private transfers in the survey year. ${ }^{12}$

Our key dependent variables on charitable giving are constructed using the following questions, which were posed to PSID survey respondents: "During the year 2000, did [you/you or anyone in your family] donate money, assets, or property with a combined value of more than $\$ 25$ to religious or charitable organizations?" Furthermore, the detailed PSID philanthropy module provides information

${ }^{10}$ We use the information from 1997 immigration module to construct our measures of immigration experience.

11 We exclude the Survey of Economic Opportunity (SEO) sample in PSID in our investigation.

12 More formally, our continuous measure of formal and informal giving is defined as $\log (1+$ total amount) 
on giving to specific charitable organizations for the entire sample. To study private transfers, we rely on the following question: "In (2000), did you give any money toward the support of anyone who was not living with you at the time?" [excluding child support and alimony payments], and "How much money [towards the support of anyone who was not living with you] was that altogether in (2000)?”

Table 1A provides summary statistics. On average, immigrant households are less likely to give to the charitable organizations than native households (45 percent of immigrants versus 68 percent for the native population). The average donation is nearly 2.4 times higher among native-born households. We also examine the itemization of charitable giving and find that immigrants are much less likely to itemize ( 27 percent of immigrants itemized versus 45 percent for the native born population). As a percentage of total income, native-born households contribute about 2.6 percent of annual household income to charitable institutions while immigrant households contribute about 0.8 percent of annual household income to charitable organizations.

In contrast, immigrants are more likely to participate in private transfer networks. About 18 percent of immigrant households gave private transfers to non-household members in the survey period while only 10 percent of the natives report private transfers. The mean private transfer is about 1.1 times higher among immigrant households compared to natives (the mean private transfer is $\$ 543.16$ among immigrant households and $\$ 487.72$ for natives).

The PSID data also allows us to examine the allocation of charitable contributions for both immigrant and native households. We have detailed information on the incidence and levels of giving for six categories of charitable institutions: religious institutions, organizations that served a combination of purposes (such as the United Way), organizations that serve the needy, health care or medical research organizations, educational, and other charitable institutions. We have information on incidence, but not specific levels of charitable giving for youth, arts, community, environment, and international aid. Table 1B presents summary statistics for eleven categories of charitable organizations.

We note that native households have higher mean rates of participation, as well as higher levels of giving in nearly all categories of giving to charitable institutions. The one exception is that immigrants have a higher rate of participation in giving to international aid organizations. In particular, we find that 3 percent of immigrant households contributed to international aid organizations, compared to 2 percent of natives. There is also a relatively small immigrant-native gap 
in religious giving where immigrant participation in religious giving is about 74 percent of the native participation rate.

The empirical literature on charitable giving emphasizes the effect of taxation on charitable contributions. Given the tax-deductibility of charitable contributions, higher marginal tax rates should lower the price of charitable giving. The price of formal charitable giving is calculated by 1 minus the marginal tax rate for itemizers, and unity for non-itemizers. We calculate the marginal tax rate for itemizers using TAXSIM version 5 (Feenberg and Coutts, 1993). ${ }^{13}$

In our analysis, we include several household characteristics, such as age of household head, age squared, marital status, gender, educational attainment, race and ethnic origin, Catholic, family size, unemployment, and household income. To account for regional variation in charitable giving, we classify households into six geographic regions based on their state of residence. There are some noteworthy differences in the demographic characteristics of our immigrant and native samples, respectively.

The immigrant sample tends to be younger, more likely to be male-headed, and contains a higher fraction of married respondents. Educational attainment is lower on average for the immigrant sample. Religious affiliation may also affect charitable giving, and we note that 61 percent of the immigrant sample is reported to be Catholic, while only 21 percent of natives report this religious affiliation. There are significant differences in the racial composition of the immigrant sample compared to the native sample. While about 88 percent of the immigrant sample is nonwhite, only 13 percent of the U.S. native sample is nonwhite. Immigrant households also tend to be larger.

The PSID has a rich set of income and wealth measures, which we exploit in order to fully capture the household's economic position. As permanent income tends to have a larger effect on charitable behavior than transitory income sources (Auten, Holger-Sieg, and Clotfelter, 2002), we use a measure of the household's permanent income. Our measure of permanent income is based on average family income from 1997, 1999, and 2001 waves of the PSID. ${ }^{14}$

\footnotetext{
${ }^{13}$ The 18 input variables used to calculate the price of giving include tax year (2000), marital status, number of children in the family unit, number of taxpayers (head and wife) over 65 years of age, labor income of the head, labor income of the wife, dividend income of head and wife, property income, pension income, gross social security income, transfer income, rent paid, property taxes paid, itemized deductions (charitable deduction and medical deduction), child care expense, and unemployment compensation.

14 Total family income can contain negative values. The number of households with negative numbers for those
} 
We note that there are important differences in income and wealth for immigrant and native-born households. Mean permanent household income is lower among immigrant households compared to natives $(\$ 42,427.00$ versus $\$ 62,099.31)$. Even after we adjust for differences in household size, we still find lower per capita permanent household income for the immigrant sample. Unemployment rates are also higher for immigrant households, suggesting that immigrants are more likely to be members of economically vulnerable groups.

\section{RESULTS}

\section{a. Charitable giving}

The first part of Table 2 (Panel A) presents regression results on charitable giving. Our main dependent variables are: (i) whether an individual contributed to any charitable organization in the survey period, and (ii) the log total amount contributed in the survey period. We report marginal effects (calculated at the variable means) for our Probit estimates. ${ }^{15}$ All estimates shown in Table 2 include controls for socio-demographic variables, the price of giving, and log permanent income. The full regression results for charitable giving are shown in Column 1 of Appendix 1.

We first present results from our baseline model, which includes the indicator variable for immigrant status. From Column 1, we note that immigrant status does not have a statistically significant impact on the probability of giving and the level of charitable giving, after we have introduced controls for permanent income and other household variables. We augment our basic specification in order to study immigrant assimilation in charitable giving.

In Column 2, we adopt a flexible specification to examine the impact of immigrants' duration of stay in the United States on charitable giving. Interestingly, we find that only recent immigrants (who migrated in the past 10 years to the U.S.) have a significantly lower likelihood of giving (the omitted category is immigrants with more than 30 years of U.S. experience). Our results suggest

variables is relatively small and we replace these negative values with missing values.

${ }^{15}$ Control variables in our analysis are age, age squared, education, gender, marital status, nonwhite, Catholic, family size, log permanent income, unemployment and region dummies. For dichotomous variables, the results represent the change in the probability, and the level of contributions associated with a change in the indicator variable from zero to one. 
that there are assimilation effects in charitable giving. ${ }^{16}$ In particular, as immigrants gain U.S. experience, their participation and levels of charitable giving appear to converge to native patterns. ${ }^{17}$

\section{b. Private transfers}

In Table 2 (Panel B), we present results for private transfers to non-household members based on a Probit and Tobit model. The key dependent variables here are defined as follows: (i) whether an individual gave a private transfer to a non-household member in the survey period, and (ii) the total amount transferred in the survey period. We define private transfers as transfers to family, friends, and neighbors living outside the household (net of transfers to children and alimony payments).

From Column 1 (Panel B), starting at the mean, we find that immigrants are 11 percentage points more likely to give private transfers. The levels of private transfers (measured in logs) are also significantly higher among immigrant households. Conditional on giving, we find that the level of private transfers is about 83.4 percent higher for immigrant households. Unlike our results on charitable giving, immigrants appear more likely to engage in private transfer networks, even after we have controlled for economic and demographic variables.

Column 2 allows us to examine assimilation effects in private transfer behavior using a flexible specification for duration of stay. Our results indicate that immigrant participation in informal giving appears relatively persistent over time. Specifically, immigrants with 10-15 years of U.S. experience continue to have higher incidence and levels of private transfers, compared to the omitted category (immigrants with more than 30 years of U.S. experience). In contrast, our results for charitable giving suggest that only recent immigrants with less than 10 years of U.S. experience are less likely to give to a charitable organization compared to the omitted category.

We also examine the interaction of immigrant status and years of U.S. experience (in years). Our results (not shown)indicate that U.S. experience is associated with a decrease in the incidence, as

\footnotetext{
${ }^{16}$ We should note that there are some limitations because we rely on cross-sectional data on charitable giving. Ideally, longitudinal data would allow us to observe a given household over time, enabling us to separately identify the role of cohort or "time of arrival" effects and duration effects in the assimilation process

${ }^{17}$ We also examine the inclusion of the immigrant's length of stay (in years) in the U.S interacted with immigrant status (results not shown). The parameter on the duration of stay variable captures how an additional year in the U.S. affects the immigrant's likelihood of giving. From our results, an additional year in the U.S. has a positive effect on charitable giving.
} 
well as the level of private transfers. In particular, an additional year in the U.S. reduces the likelihood that an immigrant will send a private transfer by about 0.5 percentage points. Again, these results present an interesting contrast to our results on formal charitable giving. While length of stay in the U.S. reduces immigrant participation in private transfer networks, it tends to increase immigrant participation in charitable giving.

\section{Robustness Checks}

One concern with the results presented above is that we have not accounted for any correlation between the error terms in the charitable giving and private transfer equations. To deal with this concern, we estimate a bivariate probit and Tobit model to examine the impact of immigrant status on charitable giving and private transfers. These results are shown in Column 3. The bivariate estimates for charitable giving (Panel A) and private transfers (Panel B) are comparable to the univariate results presented above. We also note that that we find a relatively low correlation in error terms for the charitable giving and private transfer equations (rho $=0.16$ for the bivariate probit model and rho $=0.12$ for the Bivariate Tobit model, respectively).

In addition, we investigate the possibility that omitted wealth and income differences between immigrant and native households may contribute to the immigrant-native gap in charitable giving and private transfers by including wealth in our baseline model. Our results on immigrant status and U.S. experience on charitable giving and private transfers are robust to the inclusion of wealth and alternative income measures, specifically non-labor income. ${ }^{18}$ These results strengthen our confidence that immigrant status is not merely capturing differences in income and wealth. However, we cannot rule out the possibility that unmeasured wealth and income differences between immigrant and native households may contribute to the observed immigrant-native gap in charitable giving.

Finally, we also estimate levels of charitable giving and private transfers using Powell's censored least absolute deviations (CLAD) regression model. Unlike Tobit models and other maximum likelihood estimates, CLAD estimates are robust to heteroskedasticty. Our results on immigrant status are robust when we estimate the CLAD regression model.

\section{Household Variables}

${ }^{18}$ Results are not reported here. We should note that all measures of income that we have used have a positive impact on the level of charitable giving except for transfer income. 
We now turn to discuss the impact of the price of giving, permanent income, and other household variables on charitable giving. The full set of regression results for the baseline model is presented in Column 1 of Appendix 1. The literature on charitable giving emphasizes the impact of the price of giving and income on charitable donations. Because these variables are measured in logs, we can interpret the coefficients on these variables as elasticities. Clotfelter's (1985) review of the literature points to a highly price elastic term, implying that the tax deduction stimulates more in charitable giving than its costs in terms of foregone tax revenues to the government. Our price elasticity estimate of -4.16 indicates that a 10 percent reduction in the price of giving is associated with more than a 40 percent increase in giving. ${ }^{19}$ Our estimate on income elasticity on the level of charitable giving is 1.62 .

Appendix 1 (Column 1) also allows us to study the impact of demographic variables on charitable giving for both natives and immigrants. Consistent with other studies on charitable giving, we find that there are significant life-cycle effects in charitable giving. Both the incidence and levels of charitable giving increase with age but eventually declines among older households. Male-headed households are about 4 percentage points less likely to give to charitable institutions, and the level of contributions is also significantly lower for male-headed households. Educational attainment, marital status, and household size are positively associated with both the incidence and levels of charitable giving. An additional year of education increases the likelihood of charitable giving by about 3 percentage points. Unemployed individuals are 13 percentage points less likely to give charitable donations. Interestingly, race has a negative and statistically significant impact on the probability of giving and the amount contributed. O'Neill and Roberts (2000) using data from Giving and Volunteering in California find that when controls for income, education, and immigration status are introduced, ethnic and racial differences in charitable giving tend to disappear. However, based on our results, nonwhites are about 4 percentage points less likely to participate in charitable giving even after we have controlled for permanent income, immigrant status, and other demographic variables.

Appendix 2 presents the full set of regression results for the baseline model for private transfers. We find that the price of formal charitable giving has an insignificant effect on the likelihood and the level of private transfers. Household permanent income has a positive and significant impact on the

19 In recent studies, estimates of price elasticities are considerably smaller in magnitude (Randolph, 1995; Steinberg, 1991), which casts some doubt on the price elasticity of giving claim. 
incidence and level of private transfers. Here, we note an income elasticity of 3.84 for private transfers, which is considerably larger than our estimate for charitable giving.

The impact of age on private transfers appears comparable to findings from charitable giving. There are some notable differences between the two types of transfers. For example, we find that marital status, educational attainment, and gender do not have a statistically significant impact on the incidence or levels of private transfers. This contrasts with our earlier results on charitable giving, where we found statistically significant effects for these variables. Interestingly, nonwhites are about 2 percentage points more likely to participate in private transfer networks (but we found that nonwhites were less likely to give to charitable institutions). Finally, household size has a negative and significant impact on private transfers, while household size was found to have a statistically insignificant on charitable giving.

\section{b. Organization-Specific Results}

Table 3 allows us to investigate immigrant-native differences in specific types of charitable institutions. We examine giving to religious, non-religious institutions, and international giving. The key dependent variables are defined as follows: (i) whether an individual contributed formally to this specific category in the survey period, and (ii) the log total amount contributed in the survey period (not available for international giving).

In Specification 1, we report only the coefficients on immigrant status without controls for duration of stay in the United States. From Table 3 (specification 1), immigrant status has a negative but insignificant impact on the incidence and levels of religious giving. Interestingly, immigrants appear significantly less likely to give to non-religious institutions, and their levels of giving are lower. The notable exception here is international giving where we find that immigrants are actually 4 percentage points more likely to give to international charitable activities, holding other variables constant.

Specification 2 includes controls for duration of stay. Consistent with earlier results, U.S. experience has a positive effect on charitable giving to religious institutions. In addition, we find that immigrant status no longer has a statistically significant impact on non-religious giving once we control for immigrants' duration of stay. ${ }^{20}$

${ }^{20}$ We also examine more detailed information on the impact immigrant status on giving for 11 categories of formal charitable activity. We find that immigrant status has a negative and statistically significant impact only on the incidence of charitable giving to the needy and educational and arts institutions, but not on other 


\section{c. Region of Origin}

In Table 4, we examine the impact of immigrants' region of origin on the incidence of charitable giving and private transfers. Our results include controls for duration of stay.

From Table 4, immigrants from the Middle East and Africa, and South America are less likely to participate in charitable giving compared to the excluded category (European immigrants) although these results are not statistically significant. However, we find that immigrants from Central America and Mexico are significantly more likely to participate in charitable giving than the omitted category (European immigrants). These results may provide some preliminary evidence that ethnicity and national origin influence the incidence of charitable giving, even after we have controlled for income and demographic variables. Immigrants from ethnic traditions and countries with less-similar philanthropic institutions (to the U.S.) may have lower participation rates in formal philanthropy compared to immigrants from countries with more similar philanthropic institutions, other things being equal.

Table 3 also uncovers interesting results on private transfer behavior among immigrant households. From Column 2, immigrants from the Middle East and Africa, Central America and Mexico, and the Caribbean are more likely to participate in private transfer networks. However, only Caribbean immigrants are significantly more likely to participate in private transfer networks than the excluded category (European immigrants). Again, these results are suggestive of the role of home country experience in shaping both patterns of charitable giving and private transfer behavior.

\section{d. Decomposing the Immigrant-Native Gap in formal and informal giving}

In this section, our goal is to investigate the underlying causes of the immigrant-native gaps in participation in charitable giving and private transfers. Specifically, we quantify the share of the immigrant-native gap that can be attributed to measurable characteristics (such as income, age, education, price of giving, race) and the share that is due to structural or unobserved differences across immigrants and natives. Given the non-linearity of the probit equation, we adopt a variation of the Blinder-Oaxacca decomposition (Blinder, 1973; Oaxaca, 1973). This method is detailed in Fairlie (2003).

categories of charitable giving. 
Table 5 presents estimates using the above methods for the nonlinear decomposition of the immigrant-native gap in charitable giving and private transfer behavior based on Fairlie (2003). Estimates presented in Specifications 1 and 2 are based on the coefficients from the probit model for the immigrant and native samples, respectively. These results are presented in Appendix 1.

We first discuss results from charitable giving. Although the selection of native or immigrant weights is somewhat arbitrary, it can be argued that from a policy viewpoint, that it would be most useful to consider what would happen to immigrant participation in charitable giving if immigrants retained their own functions but were given the native means. From our estimates, about 59 percent of the immigrant-native gap would remain even if immigrants had the same income, education, and other measured characteristics as natives. When native coefficients are used (Specification 2), a different picture emerges in that over 90 percent of the gap in formal giving can be explained by immigrant-native differences in characteristics.

We now turn to examine the contribution of individual characteristics to the overall gap in formal giving. Of particular interest is the relative contribution of group differences in racial background, income, and educational attainment to the immigrant-native gap in charitable giving. As expected, group differences in educational attainment and income account for a large share of the immigrant-native gap. Specifically, lower levels of educational attainment for immigrants account for 26-38 percent of the immigrant-native gap in charitable giving. Similarly, lower levels of income among immigrants account for about 21 percent of the immigrant-native gap in charitable giving, and this result appears less sensitive to the specification adopted. We note that our results suggest that group differences in age, marital status, and household size explain a relatively small share of the gap in charitable giving. ${ }^{21}$

In Table 5, we also present the decomposition results for private transfers. Specification 1 presents estimates based on immigrant coefficients while specification 2 is based on native coefficients. In both specifications, the bulk of the immigrant-native gap in private transfer transfers is attributable to differences in the coefficients rather than group differences in characteristics.

21 From the decomposition results presented above, estimates appear sensitive to whether native or immigrant coefficients are used. This is expected since the underlying processes that determine formal giving may differ across immigrant and native households. A likelihood ratio test rejects the null hypothesis that the coefficients for both specifications are identical. 
From our decomposition estimates, immigrant-native differences in charitable giving may be due to the distribution of individual characteristics (education, income, wealth, price of giving, demographic variables), as well as to the immigrant-native differences in the processes that generate formal giving. In contrast, much of the gap in private transfer behavior cannot be attributed to immigrant-native differences in characteristics. Instead, immigrant-native differences in private transfer behavior appear to be better explained by the differences in the processes that generate private transfers and/or omitted variables in our analysis, such as extended family characteristics and networks. ${ }^{22}$ An important concern with the decomposition methodology is that we cannot address the concern that observed differences in characteristics for immigrants and natives (such as income, employment status, and education) may themselves be due to factors such as discrimination or social networks (such as language proficiency, home country ties, social networks, and residential segregation).

\section{CONCLUSIONS}

There has been a growing interest on the impact of immigration on social cohesion and institutions in the United States. Standard economic indicators provide only limited insights on how immigration will affect social and economic institutions, norms, and processes. This paper provides new evidence on immigrant participation and assimilation in charitable giving in the United States. Charitable giving is thought to be an intrinsic aspect of American life and may reflect norms of trust, connectedness, and co-operative behavior.

We find that while immigrant households appear to have lower average rates of participation and levels of charitable giving, these differences are not statistically significant after we have controlled for permanent income and other household variables. In contrast, immigrants are significantly more likely to give within private transfer networks compared to native households, holding other variables constant. From our results, immigrants tend to adapt relatively quickly to U.S. philanthropic institutions. We find that only recent immigrants (who arrived in the 1990s) have significantly lower rates of charitable giving.

Our results suggest that immigrant assimilation in charitable giving occurs rapidly, with

${ }^{22}$ We include the number of parents and siblings residing outside of the U.S. in our estimation, but this does not significantly affect our baseline regression model. An additional parent or sibling residing outside of the U.S. has a positive but insignificant effect on both charitable giving and private transfers. 
implications for building social cohesion at the community and national level. We also find that private transfer behavior is relatively persistent over time, suggesting that immigrants may also have the potential to shape charitable giving and other U.S. social and economic processes over time.

\section{References:}

Auten, Gerald, Holder Sieg, and Charles Clotfelter. (2002). "Charitable Giving, Income and Taxes: An Analysis of Panel Data," American Economic Review, 92(1): 371-382.

Blinder, Alan S. (1973). "Wage Discrimination: Reduced Form and Structural Estimates," Journal of Human Resources, 8(4):436-455.

Borjas, George J. (1994). “The Economics of Immigration,” Journal of Economic Literature, 32(4): $1667-1717$.

Borjas, George J. (1985). "Assimilation, Changes in Cohort Quality, and the Earnings of Immigrants," Journal of Labor Economics, 3(4): 463-489.

Butcher, Kristin F. and Anne Morrison Piehl (1998) "Cross-City Evidence on the Relationship between Immigration and Crime," Journal of Policy Analysis and Management, 17(3): 457-93

Chao, J. (1999). “Asian-American Philanthropy: Expanding Circles of Participation”. Retrieved 2003, from http://www.cof.org/culturescaring/AsianAmerican.pdf.

Chiswick, Barry R. (1978). "The Effect of Americanization on the Earnings of Foreign-born Men," Journal of Political Economy, 86(5): 897-921.

Clotfelter, Charles T. (1985). Federal Tax Policy and Charitable Giving. Chicago, IL and London: The University of Chicago Press.

Council on Foundations and Association of Black Foundation Executives. (1993). Donors of Color: A New Promising Frontier for Community Foundations. Washington D.C.

Dayton-Johnson, Jeff. (2001). Social Cohesion and Economic Prosperity, Toronto: James Lorimer and Co.

Duleep, Harriet O. and Daniel J. Dowhan. (2002). "Insights from Longitudinal Data on the Earnings Growth of U.S. foreign-born men," Demography, 39(3): 485-506.

Duleep, Harriet O. and Mark R. Regents. (1997). "Immigrant Entry Earnings and Human Capital Growth: Evidence from the 1960-1980 Censuses," Research in Labor Economics, 16: 297-317. 
Fairlie, Robert W. (2003) "An extension of the Blinder-Oaxacca Decomposition Technique to Logit and Probit Models," Economic Growth Center Yale University, 17(1), Center Discussion Paper No. 873.

Fairlie, Robert W. (1999) "The Absence of the African-American Owned Business: An Analysis of the Dynamics of Self-Employment," Journal of Labor Economics, 17(1), 80-108.

Feenberg, Daniel and Elisabeth Coutts. (1993). "An Introduction to the TAXSIM Model," Journal of Policy Analysis and Management," 12(1): 189-94.

Joseph, J. A. (1995). Remaking America: How Benevolent Traditions of Many Cultures Are Transforming Our National Life. San Francisco, CA: Jossey-Bass.

Lubostsky, Darron. (2000). "Chutes or Ladders? A Longitudinal Analysis of Immigrant Earnings," Department of Economics University of Illinois, Urban-Champaign working paper.

Morduch, Jonathan. (1999). "Between the State and the Market: Can Informal Insurance Patch the Safety Net," World Bank Research Observer, 14(2): 187-207.

Oaxaca, Ronald. (1973). "Male-Female Wage Differentials in Urban Labor Markets," International Economic Review, 14, pp.673-709.

O'Neill, Michael and William L. Roberts. (2000). Giving and Volunteering in California. San Francisco: Institute for Nonprofit Organization Management, College of Professional Studies, University of San Francisco.

Putnam, Robert. (1993). Making Democracy Work: Civic Traditions in Modern Italy

Princeton: Princeton University Press

Putnam, Robert. (2000) Bowling Alone: The Collapse and Revival of American Community

New York: Simon and Schuster.

Qian, Zhenchao_and Daniel T. Lichter (2001). "Measuring Marital Assimilation: Intermarriage among Natives and Immigrants," Social Science Research, 30(2): 289-312.

Ramos, Henry A. J. (1999). Latino Philanthropy: Expanding U.S. Models of Giving and Civic Participation. Retrieved 2003, from http://www.cof.org/culturescaring/Latino.pdf.

Randolph, William C. (1995). "Dynamic Income, Progressive Taxes, and the Timing of Charitable Contributions," Journal of Political Economy, 103 (4):709-38

Rose-Ackerman, Susan. (1996). "Altruism, Nonprofits and Economic Theory” Journal of Economic Literature, 34(2): 701-28.

Schervish, Paul G. And John J. Havens. (1997). "Social Participation and Charitable Giving: A 
Multivariate Analysis,"Voluntas, 8(3): 261-282.

Simon, Herbert. (1993). “Altruism and Economics,” American Economic Review, 83 (2): 156-61.

Steinberg, Richard. (1991). "Does Government Spending Crowd Out Donations? Interpreting the Evidence," Annals of Public and Cooperative Economics, 62(4): 591-617.

Wilhelm, Mark, (2003). "The Distribution of Giving in Six Surveys," Department of Economics, Indiana University-Purdue University at Indianapolis. mimeo.

World Bank. (2003). Global Development Finance. Washington D.C.: World Bank. 